\title{
A PRESENCE OF A SUBSTANCE BINDING WITH THE SPECIFIC ANTIBODY AGAINST DOMOIC ACID IN THE THORNY OYSTER SPONDYLUS VERSICOLOR
}

\author{
Dao Viet Ha ${ }^{1,2}$ \\ ${ }^{1}$ Institute of Oceanography, VAST \\ ${ }^{2}$ School of Agriculture and Life Science, The University of Tokyo, Japan \\ Email: daovietha69@gmail.com
}

Received: 13-3-2014

\begin{abstract}
Domoic acid (DA) extracts from 10 specimens of a thorny oyster, Spondylus versicolor collected at Nha Phu bay, Khanh Hoa province, Vietnam in August, 2010 was analyzed individually by High Performance Liquid Chromatography (HPLC) and Indirect Enzyme Linked Immunosorbent Assay (ELISA). Domoic acid levels in the extracts detected by ELISA were always higher than those by HPLC, significantly. In the HPLC chromatogram, the peak of an unknown compound with retention time very close to DA, but different from the known DA isomers was always observed. This substance reacted well with DA-specific antibody in Western Blot experiment, but not corresponding to any standard protein. Our result indicates the occurrence of a certain non-protein substance, which was co-presented with DA in S. versicolor. Further investigation on chemical feature of this substance is under progress.
\end{abstract}

Keywords: Spondylus versicolor, domoic acid, HPLC, ELISA, Vietnam

\section{INTRODUCTION}

Domoic acid (DA) was the marine toxin corresponding for Amnesic Shellfish Poisoning (ASP) case in Prince Edward Island, Canada in 1987 [1], and a microalgae Pseudonitzschia multiseries was identified as a causative organism[2]. Then, DA was known to be produced by at least 16 diatom species belonging to Pseudo-nitzschia genus [3-5] and Nitzschia navis-varingica [6]. After Canadian incident, no human poisoning corresponding to DA has been found, but this toxin has been found naturally in numerous planktivorous species [4]. DA is also often found to accumulate in organisms that are not filter feeding such as swimming crab [7], squid and octopus $[8,9]$, and in such cases, the origin of DA is not clear.
During investigation of DA in Nha Phu bay, Khanh Hoa province, Vietnam, we found a correlation of DA levels in S. versicolor and in plankton net samples with the abundance of Pseudo-nitzschia cell numbers [10, 11]. However, DA amount in plankton sample was always so small to be accumulated in the Spondylus [10-12]. Also, the time lag (about two weeks) between DA in S. versicolor and plankton sample could not explain well plankton origin of DA in this bivalve.

With the specimens collected Nha Phu bay, Khanh Hoa province, we presented some results on the occurrence of DA related substances in Spondylus versicolor in which DA accumulation was observed previously. This data may suggest an idea of another possible origin of DA in bivalves. 


\section{MATERIALS AND METHODS}

Specimen collection: 10 specimens of $S$. versicolor were collected by SCUBA diving from Nha Phu bay, Khanh Hoa province, Vietnam in August, 2010. They were kept cool and transferred to the laboratory of Department of Biochemistry, Institute of Oceanography, Vietnam as soon as possible.

Extraction: After being removed the shells, whole tissues of each $S$. versicolor specimen were combined and homogenized with 4 volumes of distillate water, boiled in 5 minutes, and centrifuged $(10,000 \times g, 20 \mathrm{~min})$ according to Quilliam, 2003 [13]. $1 \mathrm{~mL}$ of the crude extract thus obtained is equivalent to about 0.2 $\mathrm{g}$ of the edible parts. The extracts were kept in $20^{\circ} \mathrm{C}$ until use.

HPLC and ELISA analysis: The supernatant was analysed for DA by UV-HPLC according to Kodama and Kotaki [14] and expressed as $\mu \mathrm{g} / \mathrm{g}$ of soft tissue for $S$. versicolor. The reference standard of DA (DACS-1C) was purchased from the Institute for Marine Biosciences, National Research Council of Canada (Halifax, NS, Canada). DA in $S$. versicolor crude extracts were analysed by ELISA using a DA specific antibody according to Takata [15].

Electrophoresis and WESTERN Blot analysis: The same $S$. versicolor crude extract was applied into SDS-PAGE system (Bio Craft Model BE-220, double rooms) with $15 \%$ acrylamide separating gel in 1 hour and 30 mins. After that, one gel was stained with protein staining solution (Coomassie Brilliant Blue), while another gel was transferred into Immobilon-P Transfer Membrane (PVDF membrane; pore size $0.45 \mu \mathrm{m}$ ) by Trans-Blot SD Semi-Dry Transfer Cell (Bio Rad) in $100 \mathrm{mV}$ in 1 hour and 15 minutes. Next, the membrane was incubated with DA-antibody in 1 hour with gentle sharking in room condition. Then it was stained with the $2^{\text {nd }}$ antibody IRDye680RD Goat (polyclonal) Anti-Rabbit IgG $(\mathrm{H}+\mathrm{L})$ in 1 hour in dark with gentle sharking in room condition. Image was taken by Odyssey Western Blot Blocker (LICORModel 2800) at wave length $700 \mathrm{~nm}$.

\section{RESULTS AND DISCUSSION}

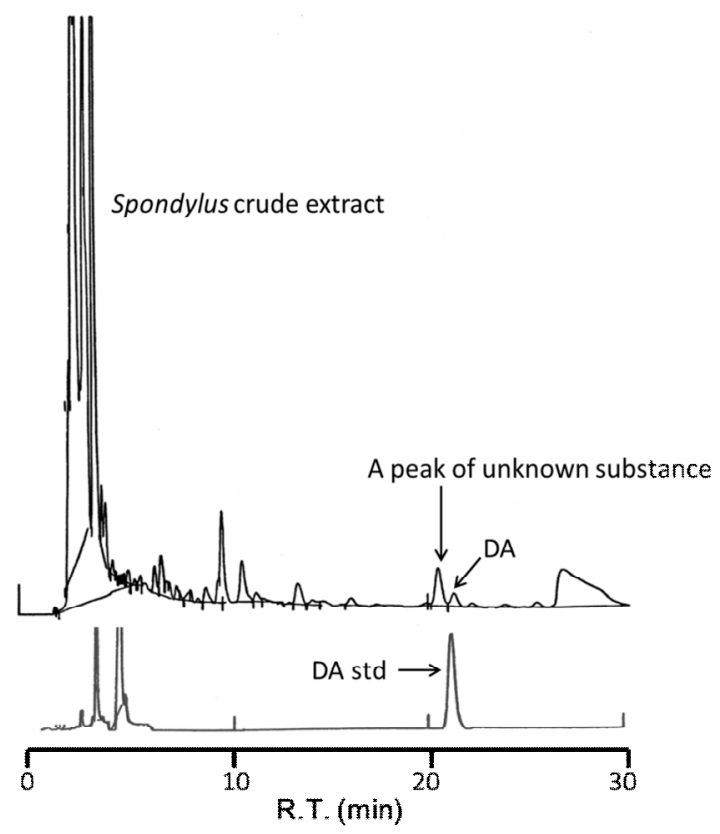

Fig. 1. HPLC chromatograph of S. versicolor extract No. 1 and DA standard

Fig. 1 showed the HPLC chromatogram of a $S$. versicolor extract and DA standard. A clear peak identically corresponding to DA standard was obtained in the S. versicolor extract. In addition, the occurrence of another peak was always observed with a retention time of less than 1 min earlier than that of DA itself. DA was originally isolated from a macro red algae Chondria armata as an insecticidal agent [16]. Its derivatives (iso-domoic acids $\mathrm{A}, \mathrm{B}, \mathrm{C}, \mathrm{G}$ and $\mathrm{H}$ ) were also isolated from the same algae $[17,18]$, but none of them have been found in the extracts of planktons or shellfish tissue. Other derivatives were isolated from toxic shellfish and a causative diatom Pseudonitzschia multiseries (e.g. iso-domoic acids D, E, F and 5-epi-DA) [19, 20]. But these derivatives have been known as geometrical isomers of DA and are not considered to be de novo products of the plankton. In HPLC analysis of shellfish extract, iso-D and $\mathrm{E}$ often appeared about $1 \mathrm{~min} 30 \mathrm{sec}$ to 2 mins earlier than DA itself due to the difference of their molecular weights [13]. Kotaki [21] also reported the occurrence of some DA isomers 
such as DA isomer A, B, C and D from the Pseudo-nitzschia genus in tropical area. However, the peak in the present study was so high in comparison with the peaks of DA isomers which often occurred in Spondylus extract [22].

Table 1: DA ( $\mu \mathrm{g} / \mathrm{g}$ soft tissue) in Spondylus versicolor detected by HPLC and ELISA

\begin{tabular}{|c|c|c|c|}
\hline Spondylus No. & HPLC & ELISA & $\begin{array}{c}\text { DA-ELISA/DA- } \\
\text { HPLC }\end{array}$ \\
\hline 1 & 0.81 & 1.97 & 2.4 \\
\hline 2 & 3.49 & 4.58 & 1.3 \\
\hline 3 & 0.92 & 2.19 & 2.4 \\
\hline 4 & 1.89 & 2.89 & 1.5 \\
\hline 5 & 1.76 & 3.18 & 1.8 \\
\hline 6 & 1.17 & 2.45 & 2.1 \\
\hline 7 & 2.05 & 2.28 & 1.1 \\
\hline 8 & 0.62 & 0.90 & 1.5 \\
\hline 9 & 0.76 & 1.03 & 1.4 \\
\hline 10 & 1.07 & 1.07 & 1.0 \\
\hline
\end{tabular}

Table 1 showed the results of ELISA and HPLC analysis of DA in crude extracts of 10 Spondylus specimens. As shown, 9 out of 10 ELISA results showed significantly higher (mean: 1.65, $\mathrm{n}=10$ ) levels of DA than those in HPLC results, strangely. According to Takata [15], there is a high correlation between ELISA and HPLC method in DA analysis $(\mathrm{R}=0.902$; $\mathrm{n}=100)$. So, the difference in DA amounts of $S$. versicolor obtained by HPLC and ELISA was affected by unknown factors rather than analysis method. On the other hand, peak of unknown substances was not detected in the Spondylus extracts which have no presence of DA. Interestingly, such extracts were negative in DA-ELISA analysis (data not shown). From these, it could be considered that the unknown substance detected by HPLC was the same substance which reacted with DA antibody in ELISA.

Fig. 2 showed the results of the electrophoresis gel after being dyed with Coomassie Brilliant Blue (CBB) (a) and the PVDF membrane after Western Blot (b). There is a clear band which reacted with specific antibody against DA (Fig. 2b). From the distance among the bands in Fig. 2, it is noticed that this band is not corresponding to any protein bands in the gel being dyed with CBB. Also, although this band reacted with specific antibody against DA in Western Blot, it could not be DA itself, because DA molecular weight is too low (311daltons) for remaining in the PDVF membrane during membrane transferring process. This substance is not also an isomer among the known DA isomers which often found in shellfish extract, as DA antibody almost does not react with these isomers [15, $22]$, the substance may not a protein, as from the result of SDS-PAGE, no corresponding band to standard proteins was observed.

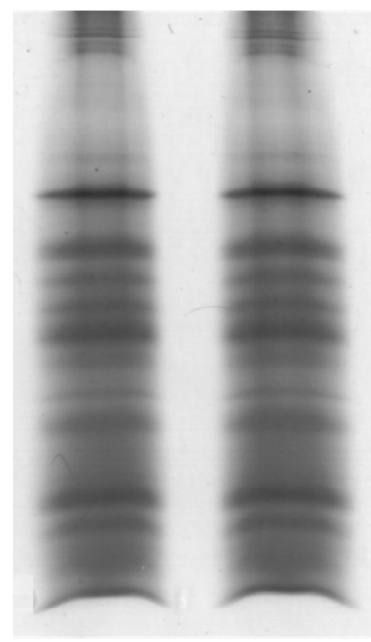

(a)

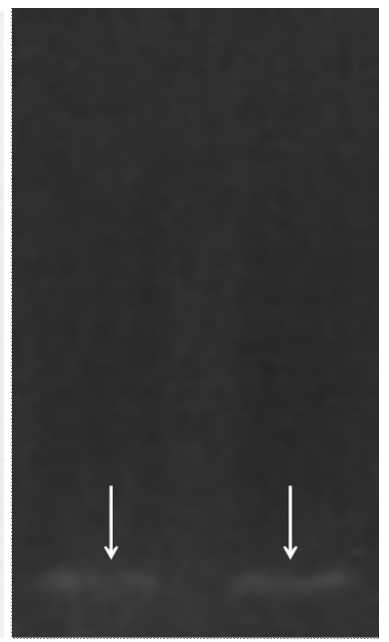

(b)
Fig. 2. SDS-PAGE of Spondylus versicolor extract (a) dyed with Coomassie Brilliant Blue and (b) Western Blot of SDS-PAGE gel

Moreover, supporting this assumption, almost all proteins may be destroyed at high temperature during the extraction process in our experiment. Western Blot data could explain well why always ELISA showed higher amount of DA than HPLC. In fact, the ELISA result is included both DA and such a substance reacting with DA-antibody. Further investigation of isolation and identification of chemical feature of the substance is under progress.

Kodama (2000) [24] reviewed that tetrodotoxin and saxitoxin are intermediate products of biosynthetic pathway, in which 
final substances are essential amino acids (lysine, arginine ...) in the living organisms. $S$. versicolor was reported as a specific species to accumulate DA in tropical regions [23, 10]. However, mechanism of toxin accumulation in this bivalve is still unclear. In case of Pseudonitzschia, Ramsey (1998) [25] reported that DA was assembled by condensation of two separate precursor units, both originating from acetate, but derived by different pathways (TCA cycle and GAP-pyruvate). Kodama et al. (1985) [26] found the presence of TTX secreting glands in the skin of toxic puffer. It was indicated that puffer cannot get any benefit from TTX, moreover, this substance may be also toxic to puffer, therefore, highly toxic specimens tried to release toxin as much as they can. It may be true also in case of DA, when Spondylus bodies accumulate DA in a high amount, this animal may try to excrete this toxin [26]. From this, it is possible that DA is not its internal substance of Spondylus species. Instead of that, unknown microorganisms living in Spondylus tissues or cells may metabolize a certain substance into other secondary substances such as DA. Our future research is going toward this direction for clear understanding on pathway of DA in nature organisms.

\section{CONCLUSION}

There is co-occurrence of the unknown substance with domoic acid (DA) in the thorny oyster Spondylus versicolor collected in Nha Phu bay, Khanh Hoa province, Vietnam. This substance could bind well with DA specific antibody, interestingly. However, it was not either any DA known isomers which were often found in DA producing plankton or shellfish nor protein. Further chemical analysis is undertaken in order to have clear understanding on chemical structure and feature of this substance.

Acknowledgment: This study was funded by the project 106.99-2010.22 - NAFOSTED, Vietnam. I am in debt to guidance from Prof. Dr. Masaaki Kodama for experimental design and writing. I wish to send my sincere thank to Prof. Dr. Yasuwo Fukuyo, Prof. Dr. Hideki Oshio and Dr. Gen Kaneko for providing lab facilities and working condition.

\section{REFERENCES}

1. Wright J. L. C., R. K. Boyd, A. S. W. De Freitas, M. Falk, R. A. Foxall, W. D. Jamieson, $M . \quad V$. Laycock, A. W. McCulloch, A. G. McInnes, P. Odense, V. P. Pathak, M. A. Quilliam, M. A. Ragan, P. G. Sim, P. Thibault, J. A. Walter, M. Gilgan, D. J. A. Richard and D. Dewar. 1989. Identification of domoic acid, a neuroexcitatory amino acid, in toxic mussels from eastern Prince Edward Island. Canadian Journal of Chemistry, 67: 481490.

2. Bates, S. S., C. J. Bird, A. S. W. de Freitas, R. Foxall, M. Gilgan, L. A. Hanic, G. R. Johnson, A. W. McCulloch, P. Odense, R. Pocklington, M. A. Quilliam, P. G. Sim, J. C. Smith, D. V. Subba Rao, E. C. D. Todd, J. A. Walterand J. L. C. Wright, 1989. Pennate diatom Nitzschia pungens as the primary source of domoic acid, a toxin in shellfish from eastern Prince Edward Island, Canada. Canadian Journal of Fisheries and Aquatic Sciences, 46: 1,2031,215 .

3. Le Long, A., H. Hegaret, P. Soudant and S. S. Bates, 2012. Pseudo-nitzschia (Bacillariophyceae) species, domoic acid amnesic shellfish poisoning: revisiting previous paradigms, Phycologia, 51: 168216.

4. Fernandes, L. F., K. A. Hubbard, M. Richlen, J. Smith, S. S. Bates, J. Ehrman, C. Léger, L. L. Mafra Jr., D. Kulis, M. Quilliam, D. Erdner, K. Libera, $L$. McCauley, and D. Anderson, 2014. Diversity and toxicity of the diatom Pseudo-nitzschia Peragallo in the Gulf of Maine, Northwestern Atlantic Ocean. Deep-Sea Research .II. http://dx.doi.org/10.1016/j.dsr2.2013.06.02 2. In press.

5. Teng, S. T., H. C. Lim, P. T. Lim, V. H. Dao, S. S. Bates, and C. P. Leaw, 2014. Pseudo-nitzschia kodamae sp. nov. (Bacillariophyceae), a toxigenic species from the Strait of Malacca, Malaysia. Harmful Algae. DOI: 10.1016/j.hal.2014.02.005. In press. 
6. Kotaki, Y., K. Koike, M. Yoshida, C. V. Thuoc, N. T. M. Huyen, N. C. Hoi, Y. Fukuyo and M. Kodama, 2000. Domoic acid production in Nitzschia sp. (Bacillariophyceae) isolated from a shrimpculture pond in Do Son, Vietnam. Journal of Phycology, 36: 1,057-1,060.

7. Wekell, J. C., E. J. Gauglisz, H. J. Jr. Barnett, C. L. Hatfield and M. Eklund. 1994. The occurrence of domoic acid in razor clam (Sliquapatula), Dungeness crab (Cancer magister), and anchovies (Engraulismordax). Journal of Shellfish Research, 13: 587-593.

8. Costa, P. R., R. Rosa and M. A. M. Sampayo, 2004. Tissue distribution of the amnesic shellfish toxin, domoic acid in Octopus vulgaris from the Portuguese coast. Marine Biology, 144: 971-976.

9. Costa, P. R., R. Rosa, A. Duarte-Silva, V. Brotas and M. A. M. Sampayo, 2005. Accumulation, transformation and tissue distribution of domoic acid, the amnesic shellfish poisoning toxin, in the common cuttlefish, Sepia officinalis. Aquatic Toxicology,74: 82-91.

10. Dao, V. H., Y. Takata, T. Omura, S. Sato, Y. Fukuyo and M. Kodama, 2009a. Seasonal variation of domoic acid in Spondylus versicolor in association with that in plankton samples in Nha Phu bay, Khanh Hoa, Vietnam. Fisheries Science, 75: 507-512.

11. Dao, V. H., Y. Takata, T. Omura, N. T. Dung, N. T. Hong, S. Sato, Y. Fukuyo and M. Kodama, 2009b. Domoic acid in smallsized plankton in Nha Phu bay, Khanh Hoa province, Vietnam. La mer, 46: 117-120.

12. Dao V. H., P. T. Lim, P. X. Ky, Y. Takata, S. T. Teng, T. Omura, Y. Fukuyo and M. Kodama, 2014. Diatom Pseudo-nitzschia cf. caciantha (Bacillariophyceae), the Most Likely Source of Domoic Acid Contamination in the Thorny Oyster Spondylus versicolor in Nha Phu bay, Khanh Hoa province, Vietnam. Asian Fisheries Science, 27. In press.

13. Quilliam M. A., 2003. Chemical methods for domoic acid, the amnesic shellfish poisoning (ASP) toxin. In: Manual on harmful marine microalgae, Monographs on Oceanographic Methodology (Eds. G. M. Hallegraeff, D. M. Anderson \& A. D. Cembella).Intergovernmental Oceanographic Commission (UNESCO), Paris: 247-266.

14. Kodama M. and Y. Kotaki, 2005. Domoic acid. In The Manual for the Method of Food Sanitation Test. Ministry of Health, Labour and Welfare (ed.). Japan Food Hygienic Association, Tokyo. (In Japanese): 666-673.

15. Takata, Y., 2006. Study on the mechanism of domoic acid accumulation in shellfish. $\mathrm{PhD}$ Thesis, Kitasato University, Iwate, Japan.

16. Takemoto, T. and K. Daigo, 1958. Constituents of Chondria armata. Chem. Pharm. Bull.,6: 578-580.

17. Maeda, M., 1986. Structures of isodomoic acid $\mathrm{A}, \mathrm{B}$ and $\mathrm{C}$, novel insecticidal amino acids from red alga Chondria armata. Chemical Pharmacy Bulletin, 34: 4,892.

18. Zaman, L., 1997. Two new isomers of domoic acid from red alga Chondria armata. Toxicon, 35: 205.

19. Wright, J. L. C., M. Falk, A. G. Mcinnes and J. A. Walter, 1990. Identification of isodomoic acid D and two new geometrical isomers of domoic acid in toxic mussels. Canadian Journal of Chemistry, 68: 5-22.

20. Walter, J. A., M. Falk and J. L. C. Wright 1994. Chemistry of the shellfish toxin domoic acid: characterization of related compounds. Canadian Journal of Chemistry, 72: 430.

21. Kotaki, Y., E. F. Furio, F. F. A. Bajarias, M. Satake, N. Lundholm, K. Koike, S. Sato, Y. Fukuyo and M. Kodama, 2006. New stage of study on domoic acid producing diatoms: A finding of Nitzschia navis varingica that produces domoic acid derivatives as major toxin components. Coastal Marine Science, 30(1): 116-120.

22. Takata Y., S. Sato, V. H. Dao, U. M. Montojo, T. Lirdwitayaprasit, $S$. Kamolsiripichaiporn, Y. Kotaki, Y. Fukuyo, 
M. Kodama, 2009. Occurrence of domoic acid and isomers in tropical bivalves. Fisheries Science, 75: 473-480.

23. Dao, V. H., Y. Takata, S. Sato, Y. Fukuyo and M. Kodama, 2006. Domoic acid in a bivalve Spondylus cruentus in Nha Trang bay, Khanh Hoa province, Vietnam. Coastal Marine Science, 30(1): 130-132.

24. Kodama, M., 2000. Ecobiology, Classification, and Origin. In: Seafood and Freshwater Toxins (Ed. L. M. Botana).
Marcel Dekker, Inc. New York Basel. 125149.

25. Ramsey, U. P., D. J. Douglas, J. A. Walter and J. L. C. Wright, 1998. Biosynthesis of domoic acid by the diatom Pseudonitzschia multiseries. Natural Toxins, 6: 137-146.

26. Kodama, M. S. Sato, T. Ogata, Y. Suzuki, T. Kaneko and K. Aida, 1985. Tetrodotoxin secreting glands in the skin of puffer fishes. Toxicon, 24: 891-829.

\title{
SỰ CÓ MẶT CỦA HỢP CHẤT GẮN KÊT VỚI KHÁNG THỂ ĐẶC HIỆU KHÁNG ĐỘC TỐ DOMOIC ACID TRONG LOÀI HÀU HƯƠNG SPONDYLUS VERSICOLOR
}

\author{
Đào Việt Hà ${ }^{1,2}$ \\ ${ }^{1}$ Viện Hải dương học-Viện Hàn lâm Khoa học và Công nghệ Việt Nam \\ ${ }^{2}$ Khoa Nông nghiệp và Khoa học sự sống, Đại học Tokyo, Nhật Bản
}

TÓM TÄT: Domoic acid (DA) trong dịch chiết của 10 mẫu vật loài Hàu Hưong thu tại đầm Nha Phu vào tháng 8 năm 2010 được phân tích đồng thời bằng phuoong pháp sắc ký lỏng hiệu năng cao (HPLC) và phưong pháp ELISA sủ dụng kháng thể đặc hiệu gắn kết với enzyme kháng lại DA (DA-ELISA). Hàm luợng DA phân tích bằng ELISA luôn cao hơn so với cùng mẫu phân tích bằng HPLC. Trên sắc ký đồ HPLC, có sư xuất hiện của 1 đỉnh rất gần thời gian luu với DA, nhung không phải là một trong nhũng dẫn xuất đã biết của độc tố này. Chất này có phản ứng với kháng thể đặc hiệu kháng lại DA trong thí nghiệm Western Blot nhung lại không phải là protein. Kết quả nghiên cứu này xác nhận sụ đồng thời tồn tại của một chất nhất định với DA trong Hàu Hương. Nghiên cứu về đặc tính và cấu trúc hóa học của chất này đang được tiến hành nhằm góp phần làm sáng tỏ giả thuyết đây là sản phẩm trung gian của quá trình trao đổi chất trong cơ thể sinh vật.

Tùkkhóa: Spondylus versicolor, domoic acid, HPLC, ELISA, Việt Nam. 